\title{
THE IMPACT OF INFLUENCER MARKETING ON CONSUMER BUYING BEHAVIOR IN SOCIAL NETWORKS
}

\author{
Miglè ČERNIKOVAITÉ (D) \\ Corporate Communication Research, Faculty of Communication, Vilnius University, \\ Sauletekio al. 9 (I house), LT-10223 Vilnius, Lithuania \\ *E-mail: miglec@yahoo.com
}

\begin{abstract}
Purpose - the purpose of the article is to analyze the impact effect of Influencers marketing on consumer buying behavior by determining which partnership opportunities are most relevant.

Research methodology - the theoretical analysis of scientific literature and quantitative statistical analysis of empirical research results.

Findings - the research in Lithuania has shown that before making a decision to purchase a product or a service, most respondents are actively seeking information in social networks by reading other costumers feedback. Moreover, the survey reveals that recommendations, comments, shared information about certain brands by Influencers are the most important factors in changing buying behavior.

Research limitations - the main limitations of research may be the geographical research area - Lithuania and social networks (Facebook).

Practical implications - understanding of Influencers impact on consumer buying behavior.

Originality/Value - this scientific topic is rather new. Scientists, like Matsumura, Yamamoto, \& Tomozawa (2008), investigated Influencers and Consumer Insights impact in the Blogosphere; Thakur, Srivastava (2015) presented a Conceptual research model of Influencers impact of Customer Satisfaction and Loyalty and etc. However, there is a lack of research investigating the impact of Influencer marketing on consumer buying behavior. This research aims to fill this gap in the Lithuanian case.
\end{abstract}

Keywords: Influencer marketing, consumer buying behavior, social media, decision making, market digitalization.

JEL Classification: M3, M31, M39.

Conference topic: Digitalization of Business Processes: Trends, Challenges, Solutions.

\section{Introduction}

Influencers marketing is not a new phenomenon in marketing, opinion leaders existed a long time before. But information technologies and social networks such as Facebook and Instagram have made this process not only popular but also more accessible. Influencers can boast a lot of followers in their accounts, speak and form opinions on certain topics and make and influence the others. so if this well-known person likes a certain product or service, then after the delivery of a particular product or service most of the followers prefer what the Influencer likes.

This topic is based on the fact that the popularity of Influencers in Social Media has become so popular that it is becoming more and more important to consider not only the value they create for brands of goods or services but also responsibility for their followers.

In Lithuania, the popularity of Influencers in marketing media is very high, so Influencers advertise controversial trademarks and often provide false and misleading information to their followers and distrust their audience. Therefore, this article aims to answer the following question: what are the main effects of Influencers marketing on brand audiences? The object of the work is the marketing of opinion makers in the media.

Purpose of the article is to analyze the impact effect of Influencers marketing on consumer buying behavior by determining which partnership opportunities are most relevant for the brand audiences

The main tasks of the study:

1. Identify the peculiarities of activity of Influencers in social networks in Lithuania.

2. Analyze Social Media Influencer Marketing activities. 
3. Find out the impact of influencers on buying behavior

Methods of research: theoretical analysis of scientific literature, systematization, generalization and interpretation and quantitative methods of research (statistical analysis of the questionnaire).

\section{Influencers marketing theoretical framework}

\subsection{Influencers marketing definition}

There are various definitions of Influencer marketing, for instance, "a type of marketing that focuses on using key leaders to drive a brand's message to the larger market" (Byrne, Kearney, \& MacEvill, 2017). Extant research also believes that an Influencer is similar to an opinion leader, they define it as an Influential person with a strong personal brand. Furthermore, the Influencers are a person who is also being seen as trustable and brands use this person to spread product- and brand awareness (De Veirman, Cauberghe, \& Hudders, 2017).

Previous research has shown that Influencers are more likely to be seen as credible and trustworthy compared to a paid advertisement (Abidin, 2016). This leads to lower resistance of the audience towards the message communicated in Social Media (Duffett, 2017). The fact that consumers can choose which Influencers to follow and trust, the opinion of Influencers on brands can play the biggest impact on customers' decision journey (Belagatti, 2017). De Veirman et al. (2017) state that one major challenge for brands still is to identify and choose the right Influencers and accountability of the influence on the financial results.

According to scientist electronic Word-of-Mouth (eWOM) has greater effects on consumer decision-making compared to traditional advertising (Freberg, Graham, McGaughey, \& Freberg, 2011). Consumers have always valued other judgments higher than an advertiser and this is considered as one of the keys to Influencer marketing (De Veirman et al., 2017). The difference between a celebrity and an Influencer is that an Influencer is more accessible but also much easier to relate to since the Influencer often shares more of their personal life (Ledbetter, 2017). This can be perceived as a personal relationship between the Influencer and follower and therefore, the follower is more likely to trust the Influencer's opinions (Abidin, 2016).

Scientific research has proven that it is important that the Influencer is both well-known but also appreciated by the audience in order to execute great campaigns. Nandagiri and Philip (2018) in their research, has shown that having more followers has a positive effect on the Influencer, simply because in that case, they seem more popular. The same research tested the sensitivity of followers/ followees ratio when an Influencer has a lot of followers but only follows a few. According to the result, this might have a negative impact if the Influencer has a huge amount of followers but just a few followers (De Veirman et al., 2017). Another research shows that Influencers have the power to influence other people with their content (Abidini, 2016). Due to the increase of using Influencers as a marketing tool, companies have understood this opportunity to market their brand and products to their desired target audience.

Influencers who want to do marketing in social media, it is necessary to have their own image, unique design, style and values of communication, and most importantly, to establish a mutual relationship with their followers, to engage them in dialogue and to promote one or other of their actions. This is a charismatic person with a lot of followers in the Social Media and who form opinions that we do not personally know, we are often not alive or talked alive, but in social networks, we follow our lives vigorously and we are interested in every detail.

The popularity of Influencers in media marketing is rising every year in Lithuania. The mentioned situation can be justified by the fact that from 2013 to 2016 the popularity of Influencers in the marketing media increased 90 times, and in 2017, the popularity of Influencers doubled (Černikovaité, 2018).

\subsection{Factors of influence on consumer behavior online}

Chaffey (2014), Anderl, Schumann and Kunz (2016) and Sabaityte (2017) present in their scientific research the factors of consumers' decision to buy online which splits into 4 stages (see Figure 1).

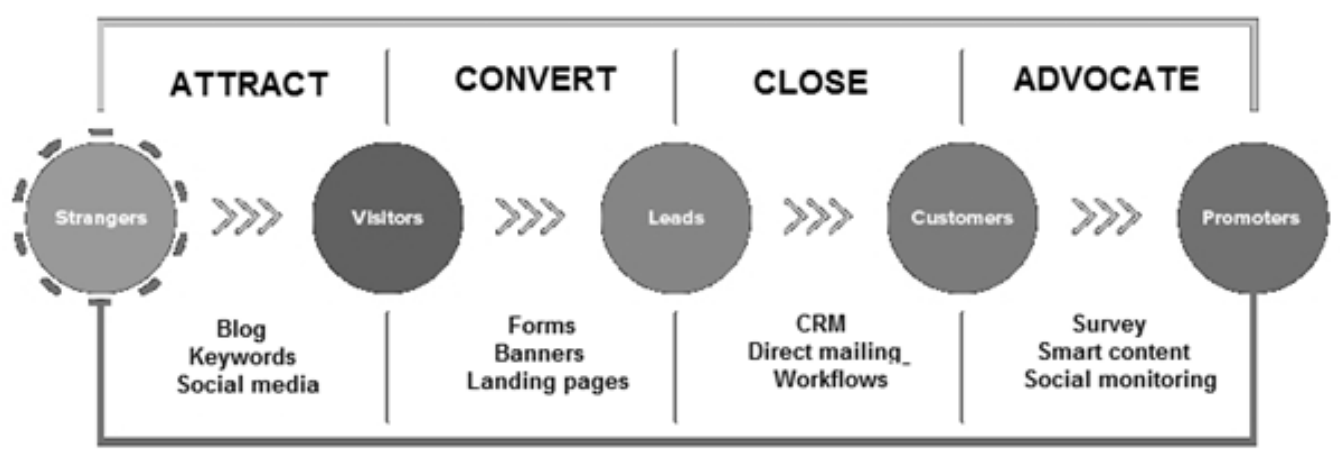

Figure 1. Consumer behavior journey online (source: Chaffey, 2014) 
Consumer attraction and information retrieval stage. Included online activities through channels where users are accustomed to visiting and meeting information, entertainment, personal goals, interactivity, collaboration, and other needs. This encourages a consumer-initiated search for information about a product or service. At this stage, the following points are important: convenience-oriented content, communities of interest, links to other pages, and more. The more channels are used in the reading phase, the less likely loyalty to the brand and the consumer can choose another supplier for the price. It is therefore particularly important at this stage for consumers to have access to the channels that are acceptable to them.

Conversion stage. At this stage, the buyer becomes an important commodity, safety-enhancing elements of the navigation website that accompany the consumer in the purchasing process and help to implement the procurement task. At this stage, a consumer conversion occurs - a potential buyer becomes a buyer after the transaction. The communication with the user at this stage becomes an important aspect of the placement of call-to-action elements and their emergence in the right place and at the right time.

Closing stage. Ensures users return through the contact information provided by the user. The company must enable the user to contact themselves through user-initiated channels. The more channels the user uses, the more he will seek out-of-the-box service to get the information they need to make decisions. Such users are described as susceptible to the inconvenience caused by the purchase and can be transferred to other channels.

Advocacy stage. At this stage, the focus is on the ability of consumers to share their experience with a consumer product or service in order to attract new users at lower costs.

In summary, Social Media helps consumers to expand their social interactions with people they would not otherwise know. Social Media helps users in different segments, which facilitates the distribution and financial gain of company products. Social Media is used inside the organization (Social Media is used only by internal members) and outside (Social Media is used not only by the members of the organization, the connection between the member and the member is possible). Starting to use Social Media has made things much more flexible and easier for businesses. The customer is available at any time from anywhere, and companies can respond quickly to customer feedback and new ideas.

\subsection{Influencer impact on consumers' decision in social media}

Social networks have become a place where a passive user has become an active, informed, informed user. (Belagatti, 2017). Thanks to the emergence of social networks, consumers have started sharing their opinions and experiences about goods and services with other users. According to Jalilvand and Samiei (2012), potential purchasers of products often read reviews of product reviews by virtual Influencers because they are interested in getting more information from people who buy and use the product they are interested in (Barzdaite \& Abromavičius, 2016).

More and more consumers are looking for feedback on a product or service online and trusted by opinion formers to find out what the buying and product information has on the consumer's decision to buy a product or service (Jalilvand \& Samiei, 2012; Barzdaite \& Abromavičius, 2016).

The point of Influencers is to raise brand awareness and promote sales. Influencers' comments and recommendations on social networks contribute directly to both of these goals (Edson, Escalas, \& Bettman, 2015). A lot of people draw attention to the comments and recommendations of Influencers, which can help the brand to connect with potential users. People are more confident about the recommendations of the Influencers than the usual advertising. It is likely that people relying on the leader of the opinion, purchasing the product or service and remaining satisfied with it will be the buyers of this product or service in the future (Černikovaitè, 2018).

All of these Influencers have created a strong personal brand image, have a clear field of activity, image, and values. They naturally reach the number of followers on social networks and their audience is fairly consistent with hobbies, relationships, and even social status. They have an authentic voice, an opinion and are loyal to it, they involve their followers in dialogue and promote their functioning (Černikovaitè, 2018).

Figure 2 shows the impact of Influencers on the brand.

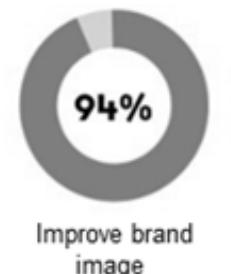

image

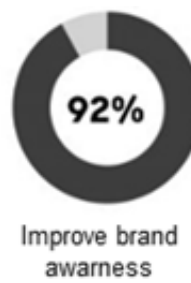

awarness

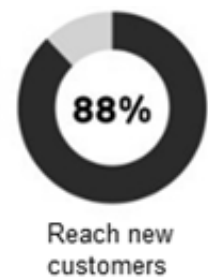

customers
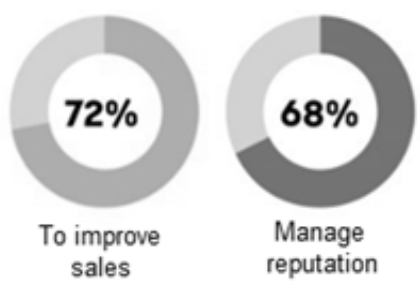

Figure 2. Impact of Influencers on the brand (source: Černikovaitė, 2018)

Increases brand awareness online: after mentioning a brand, this mention is shared, commented, or clicked "like" by its followers. Comments and sharing of the trademark entry will also be seen by the followers of the contributor. In this way, information about the brand is spreading more widely and this spread is growing naturally. The Influencer 
can reach different, even very specific, groups of people (Bush, Martin, \& Bush, 2004). And this is a great advantage when the brand's target audience is niche. In this case, it is worth choosing to collaborate not with a well-known person, but with the Influencer who is listening to that narrow brand-specific audience.

The following are the factors influencing the impact of opinion leaders on consumer decision-making in social media:

- To transmit an important message. So one of the advantages of this choice is that the message will be transmitted. Whatever the purpose, opinion leaders will help to achieve it.

- Increased brand awareness and popularity. One of the secrets of business success is that it is awareness and popularity, so these two aspects need to be strengthened in every possible way and advertising through opinion formers, one of them.

- Create a link between the brand and the audience. If a consumer is able to find a product or service that is right for him, then many people who find a product or service that suits them often use it for many years. However, in order for this to happen, first and foremost, there must be a link between the brand and the consumer. Opinion makers can justify this expectation - this is one of the best ways to establish a link between the user and the brand.

- Attract the target audience. There are goods and services that are exclusively tailored to specific categories of people. It is therefore very important that information about a product or service attracts people from certain segments. Well, Influencers' advertising, in this case, is very valuable - you just have to use a specific opinion-form maker and the message about the service or product will be delivered very efficiently.

As we can see, the business, after evaluating the impact of Social Media Influencers on consumers' decision to buy themselves, buys the opinion of the Influencers, asking for a positive opinion about their products or services. Influencers have developed a close relationship with their users and have gained their trust. In this way, the user believes that the Influencers are a reliable way to learn about certain products or services. Such people usually have more than ten thousand followers - since then, people are considered to have a status.

\section{Methodology}

The quantitative survey method - questionnaire survey - was chosen for the study. The questionnaire was conducted online. The stages of organizing the study are presented in Figure 3.

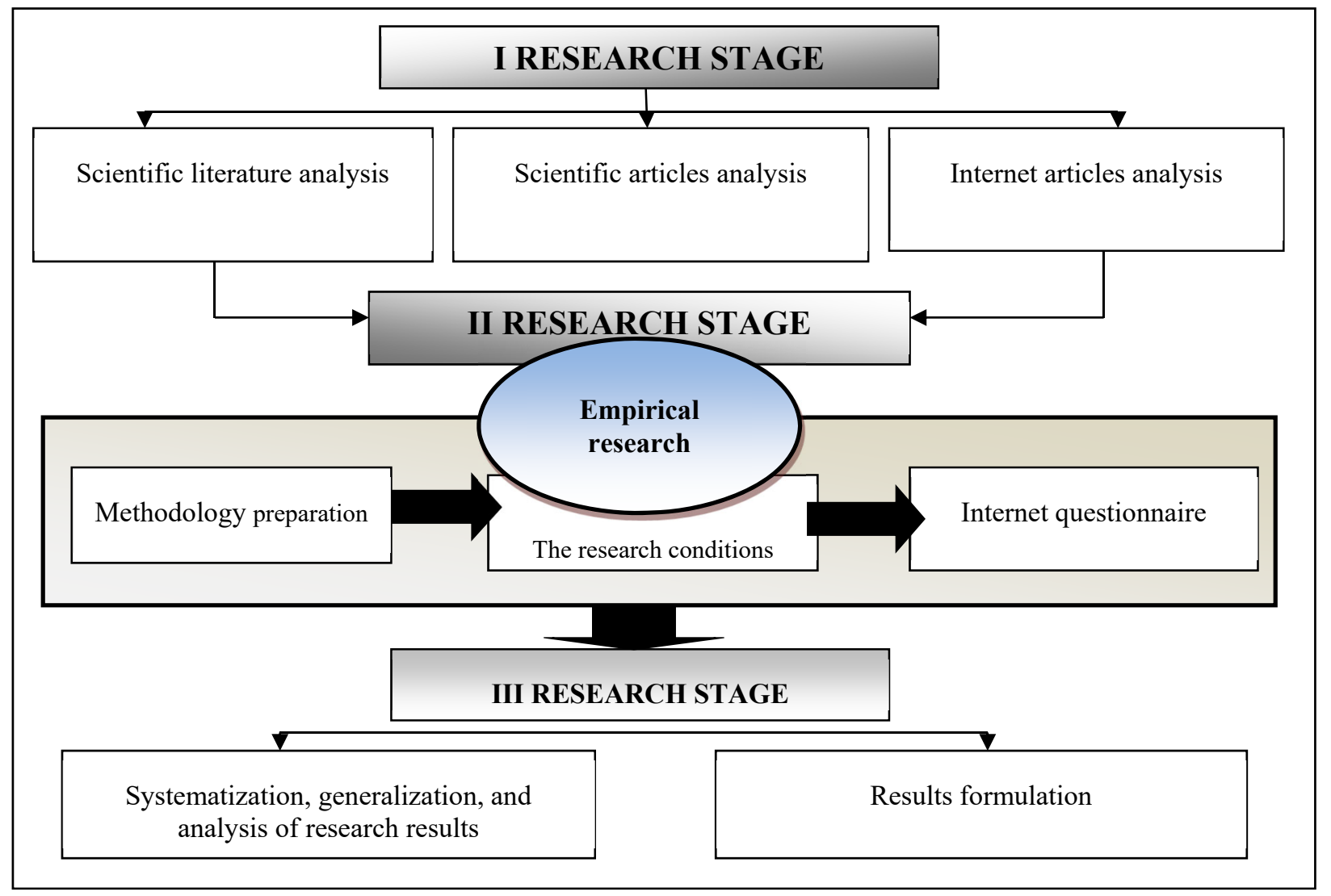

Figure 3. Stages of the research organization (source: author elaboration) 
The empiric research was conducted by using a quantitative survey method - a questionnaire online. Quantitative research is more characterized by the desire to look for external phenomena by producing various indicators that can be quantified and measured. Selecting the quantitative method of research will reveal its scientific value with the quantitative indicators obtained. The quantification study must be structured and pre-planned, as the test methods and the measuring instruments chosen are already planned and constructed before the study is started. The questionnaire should be designed so that it is not too heavy and clearly understandable to the subjects. It must involve the researcher involuntary participation, cooperation, and the willingness to participate before the end of the survey (Dikčius, 2011). Kardelis (2016) points out that the questionnaire survey can be carried out at the initial stage of the study, as well as in the main study, in order to find out the opinion, attitudes, and attitude of the respondents to a particular problem. This method is effective when you want to interview a large number of people or groups.

The questionnaire consisted of 23 questions, divided into four question blocks. The first block of questions is about demographic issues (gender, age, education, activity, income). The second block of questions consisted of questions to find out about the evaluation of influencers impact of consumer behavior in social media. The third block of questions consisted of questions to evaluate the purchase process online. The fourth block of questions consisted of questions aimed at analyzing the influence of the opinion makers in marketing media on the purchasing process. The questionnaire was chosen because of the simplicity of the survey, the cheapness, the possibility to quickly and easily collect the research data.

Respondents for the survey were selected by a targeted selection method. The method of targeted selection is the method by which the researcher selects people according to the purpose of the research (Kardelis, 2016). In this case, the survey involved people who use the Internet, buy goods in e-shops, or monitor influence and buy their advertised goods or services. The number of respondents is 297 . Confidence interval $3.4 \%$. Respondents had to mark the answer to their questions in the questionnaire or they could write their answers. The study was conducted on 19-30 November 2018. In the study, people participated voluntarily, their anonymity was guaranteed, and all ethical principles were respected.

\section{Results}

Demographics. The majority of respondents were women $(61.1 \%)$. Another part - men $-38.9 \%$. The study population is dominated by individuals with higher education (46.5\%). More than one-fifth of the respondents had secondary education $(21.1 \%)$. With higher education, there were $14.9 \%$ of respondents. The majority of the study was $26-40$ years old. More than one-third of the respondents were aged 18-25. The lowest proportion of respondents was under 18 years of age. The majority of respondents who have participated in the survey are currently working $(80.7 \%)$. More than a tenth of the respondents were students. The lowest proportion of respondents was unemployed. No pensioner participated in the survey. Most respondents earn more than 1000 Eur. per month. One-fifth of respondents said they earned 751-1000 Eur. The smallest share of respondents earns $<400$ Eur a month. The results of the study show that the income of informants allows them not only to observe but also to test new goods or services offered by Influencers.

The other results of the study revealed that almost all respondents used social media. As Social Media is a popular marketing strategy, and people are actively using social networks, one of the ways to draw customers' attention is the influence of opinion makers.

Only a small part $(1.8 \%)$ of the respondents during the survey stressed that they did not use social media.

Having discovered that most of the respondents use social media, another question was to find out what Social Media they use. The summarized results are presented in Figure 4.

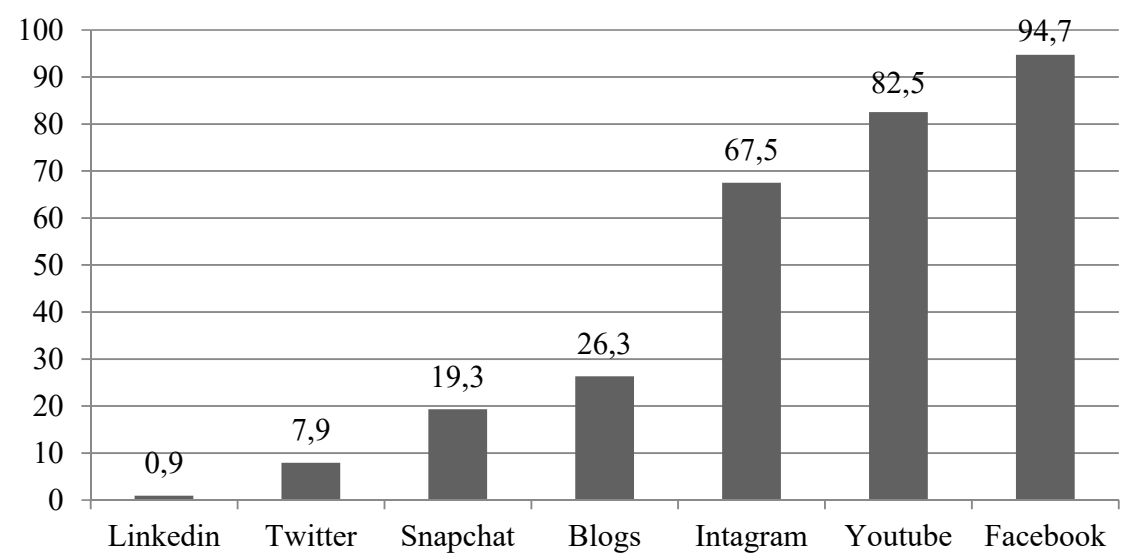

Figure 4. Percentage of Social Media used by respondents $(n=297)$ (source: author elaboration) 
The results of the study in Figure 4 revealed that most respondents use Social Media on Facebook. A little less surveyed during the survey highlighted the use of Social Media on Youtube. As we can see, these two online platforms have the highest number of users. However, the results of the study revealed that the audience of these online platforms is different. Women are more likely to join a Facebook account than men and vice versa, men are more likely to visit Youtube than women.

The TNS LT Survey conducted in 2015 is consistent with the results of our survey. The results of this study revealed that Facebook remains the most popular daily social network in Lithuania. Youtube's daily audience is a bit smaller, but within a month this social network reaches more users than Facebook.

More than half of the people who participated in the study said they were using Social Media on Instagram. Social Media is more often used by younger respondents. More than a quarter of respondents in the study said they most often read blogs/blogs, which is a very good online platform for opinion-formers to deliver goods or services to their audience. The smallest share of respondents said they were using LinkedIn and Whatsapp.

Summarized research results show that respondents choose the most socially acceptable Social Media they use most, but the results of this study revealed that the most popular Social Media used by Facebook and Youtube.

After evaluating the popularity of Social Media among the respondents who participated in the survey, another issue was to find out what determines the respondents' desire to buy a product or service. Five statements were provided to the subjects and asked to be evaluated by a ten-point system. Figure 5 summarizes the results of the study.

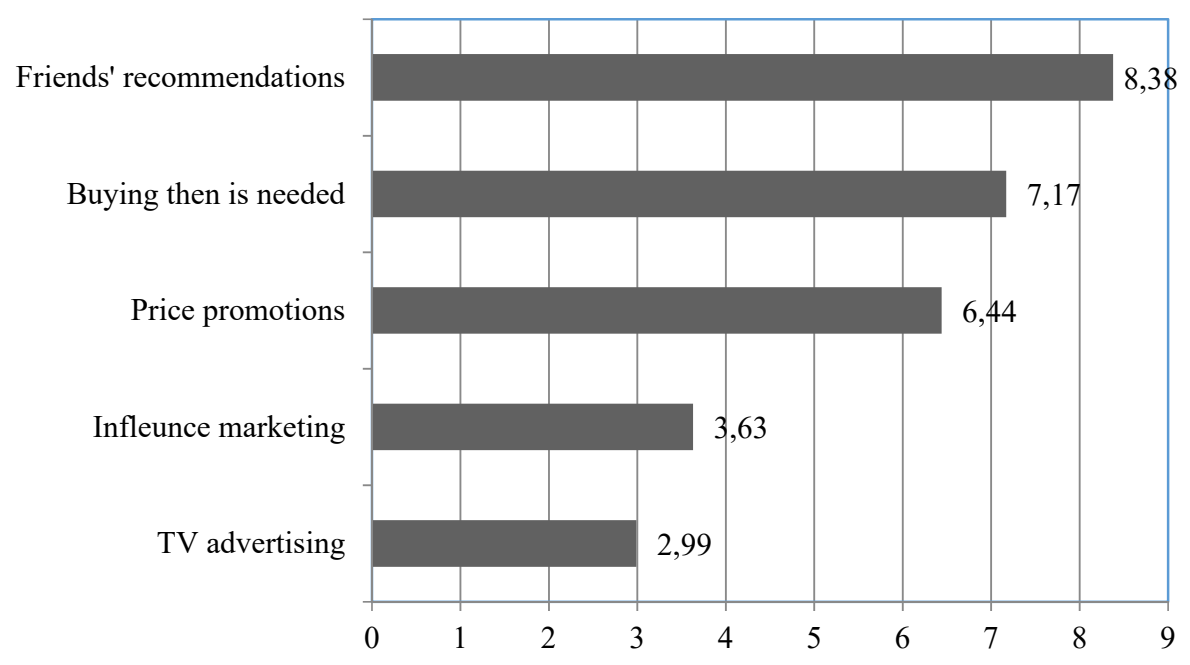

Figure 5. Factors influencing buying behavior online $(n=297)$ (source: author elaboration)

The results of the study in Figure 5 revealed that most respondents buy a product or service only when it is needed. A little less surveyed during the survey indicated that buying a product or service is influenced by a friend's recommendation, so it can be said that the personal recommendation of a familiar person is useful in the process of selling a product or service. Influencers marketing is much less affected. As we can see, a large number of people have welltrained opinion leaders who are in line with their values, overlapping views, and therefore rely on their recommendations on goods or services. Respondents are aware that recommendations made by Influencers about goods or services are hidden advertising, but appreciate it favorably and willingly buy advertised goods or services.

The consumer receives a large daily flow of news through traditional media (radio, television, magazines, and newspapers) and various social networking platforms (Facebook, Instagram, Twitter, etc.). therefore, respondents were asked to evaluate the statements made in Social Media marketing for opinion makers. The subjects were given four statements and asked for the most appropriate response option. The results of the study are presented in Figure 6.

The results of the study showed that most respondents are actively searching for information and feedback online before deciding to buy a product or service. Most people read reviews from other customers before buying a product or service, as they can find more objective information than the selling companies. Therefore, some negative feedback about a product or service may damage the brand name and the customer may question whether it is worth buying a product or service.

Similar surveys were presented by TNS LT (2012) after a population survey. The results of the research revealed that the majority of Lithuanian Internet users are looking for information about them in cyberspace before purchasing goods and services.

Slightly fewer respondents reported (avg. 3,63) that new product trends come from Social Media Influencers. As we can see, respondents rely on the information provided in social media, so Influencers actively contribute to the promotion of new goods or services. The respondents in the study emphasized that if a favorite Influencer recommends 
a product or service, it is more likely that I will test it. The least attention is given to online advertising, which means that people do not even go into the content of advertising and turn it off even without looking at it.

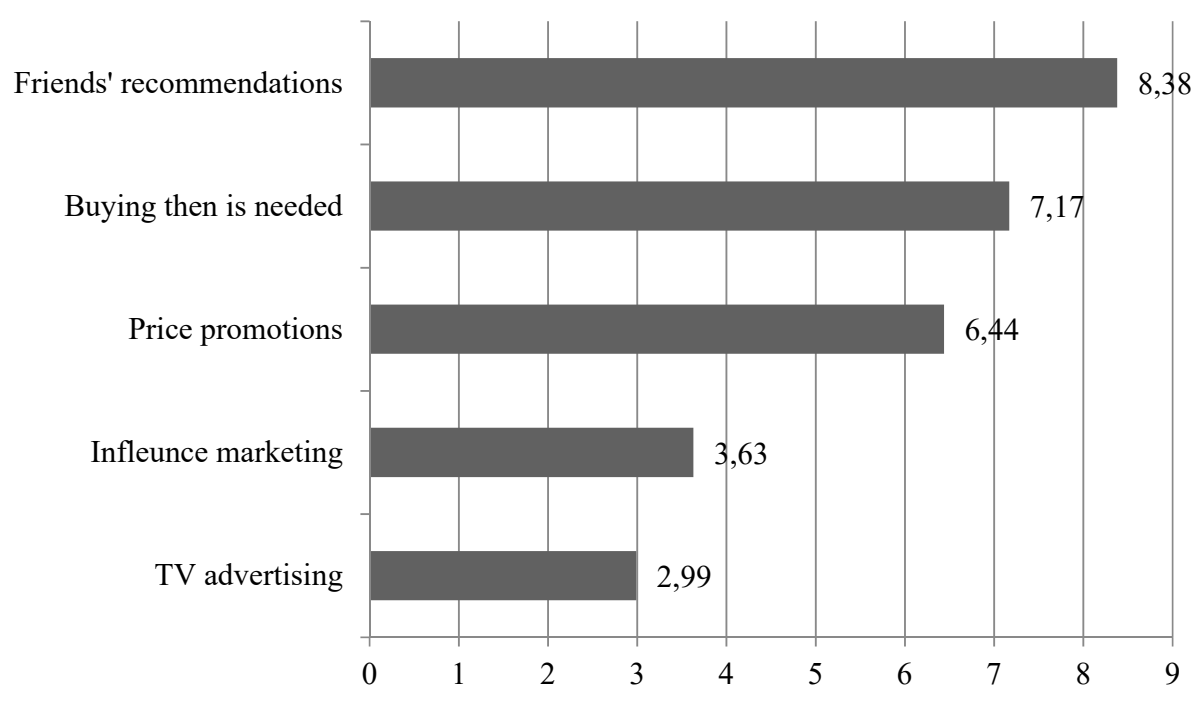

Figure 6. Evaluation of the process of purchasing a product or service online $(n=297)$ (source: author elaboration)

It can be concluded that Influencers are currently had an influence in all areas of the follower's life. They influence the process of purchasing a product or service, promote visits to events, exhibitions, show where to go and what to visit. Following up to 5 of their Influencers, respondents can try, buy and share their experiences.

The research revealed that Influencers have a major impact on the sales of goods or services, so the study was interested in how often respondents are interested in the product or service advertised by their Influencers. Most respondents during the survey indicated that they are sometimes interested in the product or service advertised by their opinion leader, which means that this group is only interested in the goods or services they need. One-third of the surveyed said that they are rarely interested in the product or service advertised by Influencer. 14\% The people who participated in the survey emphasized that they often are interested in the product or service advertised by their opinion leader, so it can be said that this group of people is an active follower of the opinion maker and is easily influenced by advertising. More than a tenth of respondents are never interested in a product or service advertised by Influencer.

Respondents follow the Influencers and test their advertised goods or services. Therefore, it was important to find out in the survey what respondents are most likely to notice about the goods or services advertised by opinion formers. More than half of the respondents in the survey indicated that they often refer to clothing and services advertised by opinion leaders. Slightly less (45.9\%) surveyed during the survey highlighted the importance of cosmetics and beauty services advertised by Influencers. Women pay more attention to these groups. $41.3 \%$ of respondents in the survey said that they often focus on events promoted by Influencers. More than a third of respondents in the survey indicated that they usually refer to electronics and technical goods advertised by opinion leaders. A quarter of those surveyed indicated that they mostly refer to household items advertised by opinion leaders and related services.

\section{Conclusions}

The use of social media influencer marketing in lifestyle public relations initiatives has broken the wall between the consumer, the brand, and followers through social media content. Before the rise of social media influencers, advertising to brand consumers was one-sided. Today, a consumer now can interact with a product through social media which he is trusting and communication between brand and customers is two-ways.

Through research in Lithuania, it is evident that social media influencer marketing has, in fact, changed the way brands interact with consumers in a positive way. The success that brands may expect is due to this two-way interactive public relations tactic and helps to explain why social media influencer marketing is one of the biggest modern trends to rise brand awareness and promote brand sales.

The results of the study revealed that before deciding to buy a product or service, most respondents were actively looking for information and feedback on the internet, reading the feedback from other customers. Infleuncers'ecommendations, comments, sharing information on certain brands, and opinion are important factors in providing information about certain brands or services and encouraging consumers to acquire and enhance brand awareness. Women are looking for such a recommendation before buying clothes, footwear, and accessories. And most of the men are looking for such a recommendation before purchasing electronic and technical goods. 
By summarizing, research - respondents in Lithuania usually first find out about the brand or service from Social Media Influencers. Influencers discuss a variety of topics, so everyone can find answers to questions about various topics of goods or services. Because Influencers and their followers often share many questions, opinion leaders can promote their values and goals by advertising goods or services and attract more followers to buy goods or services.

\section{Disclosure statement}

I declare that I do not have any competing financial, professional, or personal interests from other parties.

\section{References}

Abidin, C. (2016). Visibility labour: Engaging with Influencers' fashion brands and \#OOTD advertorial campaigns on Instagram. Media International Australia, 161(1), 86-100. https://doi.org/10.1177/1329878X16665177

Anderl, E., Schumann J. H., \& Kunz, W. (2016). Helping firms reduce complexity in multichannel online data: A new taxonomybased approach for customer journeys. Journal of Retailing, 92(2), 185-203. https://doi.org/10.1016/j.jretai.2015.10.001

Barzdaitè, A., \& Abromavičius, E. (2016). E-WOM komunikacijos vartojimo poveikis prekès ženklo ịvaizdžiui ir pirkimo intencijai. Retrieved from https://alytauskolegija.lt/wp-content/uploads/straipsniai/Barzdaite.pdf

Belagatti, P. (2017). The Importance and Impact of Influencer Marketing in 2017. Retrieved from https://www.influencive.com/theimportance-and-impact-of-Influencer-marketing/

Bush, A. J., Martin, C. A., \& Bush, V. D. (2004). Sports celebrity Influencer on the behavioral intentions of generationy. Journal of Advertising Research, 44(1), 108-118. https://doi.org/10.1017/S0021849904040206

Byrne, E., Kearney, J., \& MacEvilly, C. (2017). The Role of Influencer Marketing and Social Influencers in Public Health. Proceedings of the Nutrition Society, 76(OCE3), E103. https://doi.org/10.1017/S0029665117001768

Černikovaitė, M. (2018). Nuomoniu lyderiai - auganti niša socialiniu tinklu rinkodaroje. Retrieved from https://www.lzinios.lt/Ekonomika/nuomoniu-lyderiai-auganti-nisa-socialiniu-tinklu-rinkodaroje/.

Chaffey, D. (2014). Improving Online Experiences - The Customer Journey Report. Smart Insights. Retrieved from http://www.smartinsights.com/solution/customer-experience-strategy.

De Veirman, M., Cauberghe, V., \& Hudders, L. (2017). Marketing through instagram Influencers: impact of number of followers and product divergence on brand attitude. International Journal of Advertising, 36(5), 798-828. https://doi.org/10.1080/02650487.2017.1348035

Dikčius, V. (2011). Anketos sudarymo principai. Vilnius: Vilniaus universitetas.

Duffett, G. R. (2017). Influence of Social Mediamarketing communications on young consumers' attitudes. Young Consumers, 18(1), 19-39. https://doi.org/10.1108/YC-07-2016-00622

Edson Escalas, J., \& Bettman, J. R. (2015). Managing brand meaning through celebrity endorsement. Review of Marketing Research, 12, 29-52. https://doi.org/10.1108/S1548-643520150000012002

Freberg, K.., Graham, K.., McGaughey, K., \& Freberg. L. A. (2011). Who are the Social MediaInfluencers?. A study of public perceptions of personality. Public Relations Review, 37(1), 90-92. https://doi.org/10.1016/j.pubrev.2010.11.001

Jalilvand, M. R., \& Samiei, N. (2012). The effect of electronic word of mouth on brand image and purchase intention. Marketing Intelligence \& Planning, 30(4), 460-476. https://doi.org/10.1108/02634501211231946

Kardelis, K. (2016). Moksliniu tyrimu metodologija ir metodai. Kaunas: Judex.

Ledbetter, E. (2017). The Change in Influencer Marketing from PR Strategy to Media Strategy. Retrieved from https://blog.carusele.com/change-influencer-marketing-pr-strategy-media-strategy

Matsumura, N., Yamamoto, H., \& Tomozawa, D. (2008). Finding Influencers and consumer insights in the blogosphere. In ICWSM 2008 - Proceedings of the 2nd International Conference on Weblogs and Social Media (pp. 76-83).

Nandagiri, V., \& Philip, L. (2018). Impact of influencers instagram and Youtube on their followers". International Journal of Multidisciplinary. Research and Modern Education, 4(1), 61-65.

Sabaitytè, J. (2017). Internetinio marketingo komunikacijos sistema. Daktaro disertacija. Vilnius: Technika. https://doi.org/10.20334/2017-020-M

Thakur, R., \& Srivastava, M. (2015). A study on the impact of consumer risk perception and innovativeness on online shopping in India. International Journal of Retail \& Distribution Management, 43(2), 148-166. https://doi.org/10.1108/IJRDM-06-2013-0128 